\title{
Probáld Ferenc
}

\section{A földrajz tantervi helyzetének változásai}

\begin{abstract}
A kidolgozás alatt álló új Nemzeti alaptanterv vitájának keretében szükséges lenne újból átgondolni, hogy az egyes múveltségi területek tantervi arányának és elhelyezésének immár negyedszázados szabályozása meny-

nyiben állta ki az idók próbáját. A következókben ezt a kérdést a „Földünk-környezetünk" múveltségi területre, illetóleg az ennek lényegében megfeleló földrajz tantárgyra vonatkozóan vizsgáljuk. Mindenekelótt áttekintjük a tárgy oktatási rendszerünkben elfoglalt helyének történeti változásait, majd igyekszünk megvilágítani a jelenlegi tantervi szabályozásból eredó problémáit. Végül a nemzetközi tapasztalatokat is figyelembe véve vázolunk néhány olyan tantervi megoldást, amelyek lehetôvé tennék, hogy a földrajztanítás korszerübb módszerekkel és eredményesebben járuljon hozzá a jövó nemzedék közmúveltségéhez s boldogulásához.
\end{abstract}

\section{A földrajztanítás múltja - a kezdetektől a 2o. század közepéig}

A I6-I7. század nagy földrajzi felfedezései új távlatokat nyitottak Európa társadalmigazdasági fejlődése előtt. A tízmilliókat megmozgató, kontinensek közötti vándorlásoktól, a tengerentúli kereskedelem földrészek közt átívelő szálaitól egyenes út vezetett korunk ,globális” világgazdaságáig, amely ezernyi módon kapcsolja össze és hozza kölcsönös függőségbe Földünk valamennyi országát. S amint az európai ember mozgásának és gazdálkodásának tere a gyarmatosítás révén világméretüvé tágult, úgy vált a gyakorlatban is hasznossá és az általános müveltség részévé a geográfia. Kant (I80I, I4. o.) gyakran idézett, bizonnyal ma is helytálló vélekedése szerint ,a földrajz nélkül beszükült, korlátolt, szük látókörü ('beschränkt, begrenzt, beengt') marad az ember". A I8I9. században a nemzetállam eszméjének térhódításával a haza földjének megismerése és szeretete a kollektív összetartozás tudatának fontos elemévé vált, ami további ösztönzést adott a földrajztanításnak. A honismeret, valamint a lépésröl lépésre kitárulkozó világ megismerése iránti igény szolgálatában a földrajz önálló, megbecsült tantárgy lett a közoktatásban, majd - jelentős részben a tanárképzés igényei nyomán - meghonosodott az egyetemeken is.

A földrajztanítás hazai története - csekély késéssel - a tudomány és az oktatásügy által Európa nyugati felében bejárt fejlődési pályát követte. A földrajz önálló tantárgyként a nagy felfedezések korát követően, a I7. és I8. század jelesebb egyházi iskoláiban tűnt fel elöször (Udvarhelyi és Göcsei, I973, Fodor, 2006). A magyar oktatási rendszer kialakulásában határkőnek számító Ratio Educationis (I777) a királyi katolikus gimnáziumoknak mind az öt osztályában - heti két-két órában - elöírta a földrajz tanítását, amelynek középpontjába Magyarországon kívül a Habsburg örökös tartományok ismeretét állította.

A hazai oktatásügy történetében újabb mérföldkövet jelentő I868. évi népiskolai törvény a földrajz tanítását a népiskolában $\mathrm{s}$ a polgári iskolában is kötelezővé tette. Az Eötvös József nevével fémjelzett tanterv a gimnáziumoknak mind a hat osztályában sze- 
repeltette a földrajzot, melynek célját így határozta meg: „A Föld felületének ismerete, annak természeti és politikai felosztása szerint, különös tekintettel Magyarország földiratára" (id. Udvarhelyi és Göcsei, 1973, 59. o.). Néhány évvel később azonban a nyolcosztályossá bővült gimnáziumoknak már csupán az I-III. és VII. osztályában - ott is mindössze heti két-két órás keretben - maradhatott meg a földrajz. I873-ban olyan tervezet is napvilágot látott, amely a földrajzot és a természetrajzot egybeolvasztotta volna; ettől az elképzeléstől azonban a kultuszkormányzat - a tanáregyesület érveinek engedve - végül kénytelen volt elállni.

A dualizmus korának sorozatos tanügyi reformjai időben egybeestek a geográfia természettudományos módszerének és szemléletének erősödésével, egyszersmind az emberföldrajz színre lépésével. E forrongó időszak fejleményeit a földrajztanítás tartalmának és óraszámának változásai is tükrözték (I. táblázat). I899 és I924 között a gimnáziumoknak csupán első három osztályában tanítottak földrajzot. A korszak legkitünőbb tantárgypedagógusa, a Magyar Földrajzi Társaság (MFT) Didaktikai Szakosztályának későbbi megalapítója, Vargha György (1908, 33-34. o.) joggal írta: „,Hogy a tanuló csak akkor tanuljon földrajzot, mikor a feje-lágya még be nem nött, mikor az alapozás munkája van csupán, $s$ midön az épület épitésére és betetözésére kerül a sor, a felsöbb osztályokban a földrajzról, mint önálló tárgyról sohase halljon, az képtelenség." Ehhez csüggedten füzte hozzá: „Ha szükséges tárgy a földrajz, akkor tanitsuk a nyolc osztályon keresztül önállóan, vagy pedigfelesleges, akkor töröljük teljesen, mert a mai formában a törekvés, a buzgalom legkevésbé áll arányban az eredménnyel." Ilyen keserü szavakat földrajztanárainktól manapság is gyakorta hallani.

I. táblázat. A földrajz tantárgy órakerete a gimnáziumok, illetve I950-töl az általános iskolák és gimnáziumok tantervei szerint

\begin{tabular}{lccccccccc}
\hline & 1883 & 1899 & 1924 & 1938 & 1950 & 1956 & 1961 & 1978 & 1995 \\
5-8. о. & 12 & 8 & $8-10$ & 9 & 11 & 9 & 8 & 6 & 3 \\
9-12. о. & 0,5 & - & $2-3$ & 2 & 9 & 7 & 6 & 5 & 4 \\
\hline
\end{tabular}

Kétségtelen, hogy az iskolai földrajz nehezen tudta levetkezni a tisztán leíró, lexikális jellegü államismék örökségét, amit a kor vezető geográfusai élesen bíráltak. Cholnoky Jenő (I930, I5. o.) ezt írta: „, Az én gyermekkoromban a földrajzban csak adatokat, neveket tanultunk lexikális felsorolásban, s a szegény diák feje megzápult töle... Ma már lassanként átalakul ez a gyermekgyilkos és földrajzölö rendszer, s tankönyveink is kezdenek áttérni az okosabb oknyomozó irányra, de azért még ma is böven van belöle!"”

A két világháború között sokat fejlődött a földrajztanítás szemlélete és módszertana, értékes tankönyvek és oktatási segédletek készültek. A haza földrajza ebben az időszakban változatlanul magában foglalta az egész Kárpát-medence tárgyalását, ami kifejezte és ébren tartotta a trianoni békediktátum revíziója iránti társadalmi igényt. A legszínvonalasabb és legnagyobb óraszámú földrajztanítás a polgári iskolákat és az ezekre épülő felső kereskedelmi iskolákat jellemezte; utóbbiakban a tantárgy folyamatos oktatása érettségi vizsgával zárult. A tanterv célkitüzése gyakorlatias és - a szakgimnáziumok feladatát tekintve - máig időszerü: „, A felső kereskedelmi iskolai földrajzi tanitás a Földet mint a gazdasági élet szinterét tekinti, és a gazdasági élet különbözö jelenségeinek földrajzi magyarázatát adja meg. A tanitás célja tehát az, hogy a közgazdasági pályákra készülö ifjú megszerezze mindazokat a földrajzi ismereteket, amelyek saját hazája, idegen országok sáltalában az egész Föld gazdasági élete felöl tájékoztatják” (id. Udvarhelyi és Göcsei, I973, I34. o.). A klasszikus mủveltségi tárgyak mellett szerényebb hely jutott a földrajznak az értelmiségi pályák széles körére felkészítö gimnáziumokban; a tananyag súlypontja itt egyértelmủen az alsó tagozatra tolódott, és a névanyag elképesztő túltengése jellemezte. Az I. és 
II. osztályban óránként I3, illetőleg 20 nevet, összesen több mint kétezret kellett (volna) feldolgozni (Fodor, 2006, 427. o.). (Összehasonlításul: a jelenlegi kerettanterv négy év alatt összesen kb. 300 földrajzi név tanítását írja elő, ami inkább az ellenkező végletnek tünik, s még mindig viták tárgya. A történelem tantárgy névanyaga ennek többszöröse.) Fodor $(2006,430$. o.) az I945-ig terjedő évszázadra visszatekintve az elavult, lexikális jellegü tartalom mellett a világnézeti ütközésekkel és a földrajz sajátos, a természet- és társadalomtudományok közt hidat képező, egyszersmind szintetizáló jellegével magyarázza a tantárgy óraszámának és tantervi helyének folytonos változ(tat)ását. „Ilyen hullámszerü, tervszerütlen és kapkodó kormányintézkedésekre más tárgyak esetében egyetlen példát sem találunk" - állapítja meg. Sajnos a helyzet a következő évtizedekben se változott.

\section{A földrajz az szocialista korszak iskolarendszerében}

Az I945. évi iskolareform nyomán kirajzolódtak oktatási rendszerünk máig érvényes szerkezeti alapvonásai: a nyolcosztályos általános iskola és a négyosztályos középiskolák, amelyek közül továbbra is a gimnáziumból nyílt a legszélesebb út a felsőoktatás irányába. Az iskolák államosítása után kiadott tantervek I950-től fogva általános érvényüek, és végrehajtásukat egy-egy iskolatípus, illetve tantárgy számára központilag jóváhagyott egységes tankönyvek és oktatási segédletek szolgálták. A kezdetben még kiforratlan, hirtelenjében bevezetett tantervek többszöri átdolgozásra szorultak. Az I950. évi tanterv minden idők legbőségesebb időkeretét irányozta elő a földrajz számára (I. táblázat), aminek hátterében a kor ideológiai-politikai megfontolásai keresendők. Amint az I95I. évi módszertani útmutatás megfogalmazta: a földrajz ,elsőrendü világnézeti tantárgy lesz, a szocialista nevelés hatalmas fegyvere” (id. Udvarhelyi és Göcsei, I973, I5I. o.). Ettől fogva négy évtizeden át élesen különvált a földrajztanításon belül a tőkés és a szocialista „,világrendszer" államairól adott jellemzés. Amint azonban a hidegháborús feszültség enyhült, a földrajz által közvetített világkép is egyre tárgyilagosabbá vált. Az általános iskolai oktatás és nevelés utolsó „,szocialista” tanterve I978-ban látott napvilágot; ebben fogalmazódott meg először a környezet- és természetvédelemre való nevelés igénye, továbbá teret kapott a földrajzban az európai integrációs folyamat bemutatása is. Az I978. évi tanügyi reformot követő bő másfél évtizedes nyugalmi időszak lehetőséget kínált a földrajztanítást szolgáló módszertani segédletek (atlaszok, falitérképek, diapozitív- és fóliasorozatok, munkafüzetek, tanári segédkönyvek) átfogó rendszerének kiépítésére, ami az iskolai munka színvonalának és hatékonyságának emeléséhez nagyban hozzájárult.

I950 és 1978 között a földrajztanítás az általános iskolában és a gimnáziumban rendelkezésére álló óraszámnak csaknem a felét elveszítette (I. táblázat). A változások egy része a korábbi túlzott arányok helyesbítéseként fogható fel. A csökkenés valójában kisebb mértékü, mivel az 5. osztályban bevezetett integrált jellegü „környezetismeret” a biológia mellett a korábbi földrajzi tartalmak jórészét is magában foglalta. Sokkal fájdalmasabb veszteség a földrajztanítás szempontjából, hogy a tantárgy kiszorult a gimnázium két felső osztályából. Ennek lehetősége először az I950-es évek legvégén merült fel, amikor az Iskolai Reformbizottságban kidolgozott tervezet szerint a korábbi $2+3+2$ óra helyett a földrajz csupán a gimnáziumok első két osztályában, 2-2 órával kapott volna helyet. Az új tanterv heves vitákat váltott ki a tantestületekben s a Magyar Földrajzi Társaság szakosztályaiban. Az MFT választmánya bizottságot küldött ki a tanterv ügyeinek vizsgálatára, amely Simon László főtitkár vezetésével emlékiratot szerkesztett, s ezt eljuttatta az illetékes párt- és kormányszervekhez. Ennek eredményeképp a korábbi tervezetet elvetették, és az I96I. évi III. törvény - lényegében az MFT javaslatának megfelelően - a gimnáziumok első három osztályában heti két-két órában írta elő a földrajz tanítását (Udvarhelyi és Göcsei, I973, I54-I55. o.). A történet különösen azért figyelemre méltó, mert mutatja, 
hogy a pártállami rendszer részletkérdésekben meglepően hajlékony tudott lenni. Ez volt - legalább a földrajztanítás szempontjából - mindmáig az utolsó eset, amikor az oktatásügy legmagasabb szintjén elhatározott intézkedésben tantestületi viták és szakmai érvek hatására érdemi változást sikerült elérni.

Ami I96I-ben még elmaradt, az 1978-ban bekövetkezett: az akkor elfogadott tanterv szerint a földrajz már csak az első két gimnáziumi osztályban kapott helyet. A földrajztanításnak a gimnáziumok II. osztályában történő befejezése meghiúsította a történelem tanításával való hatékony koncentrációt, s az életkori sajátosságoknak meg nem felelö, korai szintre szorította az általános természeti és gazdasági földrajz átfogó szintézisének oktatását, végül pedig: gyakorlatilag kizárta a földrajzot a felvételi tárgyak közül azokban a (például közgazdasági, külkereskedelmi) felsőoktatási intézményekben, amelyekben a képzés iránya és jellege erősen igényelné a geográfiai alapismereteket.

A földrajztanítás óraszámának csökkenése, lehetőségeinek beszükülése ellentétes volt azokkal a sokasodó társadalmi igényekkel, amelyeket hazánk hosszú elszigeteltségének oldódása támasztott a földrajztanítás és általában a geográfiai müveltség iránt. A 70-es évektől gyors ütemben fejlődtek Magyarország nemzetközi kapcsolatai, gazdaságunk egyre nyitottabbá vált, és elindult a világgazdaság rendszerébe való beilleszkedés útján. Idegenforgalmunk korábban soha nem látott méreteket öltött, és magyarok milliói utazhattak rövidebb-hosszabb időre külországokba. Ugyanakkor sokasodtak az emberiség jövőjét beárnyékoló globális problémák, s nyilvánvalóvá lett a környezeti világválság, amelynek honi tüneteit és következményeit sem lehetett többé leplezni. Mindez új kihívást jelentett a földrajztanítás számára. Az információs társadalom térhódításával felértékelődött a földrajz tantárgy legáltalánosabb célja is: az, hogy tudományosan megalapozott, rendszerezett ismeretanyagával bizonyos szinten átfogó, koherens képet adjon világunkról, s ezzel szilárd alapot teremtsen a további önmüveléshez, a felénk áradó információk értelmes befogadásához és helyes értékeléséhez. Mindez arra utalt, hogy a földrajz szerepének a közoktatásban növekednie kell, és a rendszerváltozás után az új, korszerü követelményeknek megfelelően kell tantervi koncepcióját átalakítani (Probáld, I99I). A valóságban ennek ellenkezője történt.

\section{A földrajz és a nemzeti alaptantervek}

Nemzeti alaptanterv készítéséről még I989-ben született minisztériumi határozat, ám a dokumentum rendeletbe foglalására csak 1995-ben, felmenő rendszerben történő bevezetésére pedig I998-tól került sor. A tantervi munkálatok elhúzódása a kormányváltásokkal és ennek megfelelően a bizottságokban folyó, jobbára ideológiai-politikai természetü vitákkal magyarázható. Szélesebb körü szakmai egyeztetésekre csak 1994 végén, néhány hónapig nyílt lehetőség, ám ezek a tantervi idő felosztásának minden indoklás nélkül eleve eldöntött, „köbe vésett” arányait nem érinthették. Az alaptanterv hatálybalépése nyomán a korábbinál bonyolultabb, háromszintủ szabályozási rendszer jött létre, amelynek két további elemét a kerettantervek és az iskolai programok képezik.

Az I995. évi Nemzeti alaptanterv (NAT) iskolatípusok felett álló szabályozási dokumentumnak készült, amely a közös, minimális müveltségi tartalmakat és fejlesztési, nevelési célokat a Io. évfolyamig bezárólag, kétéves szakaszokra bontva és tíz müveltségi területbe rendezve határozta meg. Ezt kiegészítette olyan - müveltségi területek fölött álló - kereszttantervi követelményekkel és fejlesztési feladatokkal, amelyeknek az oktatás és nevelés egész folyamatát át kell hatniuk. A NAT 2003. és 2007. évi, újabb változatai az eredeti koncepción nem változtattak, csupán a kiemelt fejlesztési feladatok és kulcskompetenciák kijelölését állították előtérbe, ezenfelül pedig a 20I2. évi NAT az erkölcsi nevelési célok széles körének meghatározására helyezte a hangsúlyt. 
A NAT-ban meghatározott alapelveket a kerettantervek hivatottak a különböző iskolatípusok mindennapi gyakorlata számára „lefordítani” Ez magában foglalja a különböző tantárgyak órakeretére és annak időbeni tagolására vonatkozó útmutatást is. Minthogy a műveltségi területek - a fizikából, kémiából, biológiából összevont „Ember és természet" kivételével - lényegében megfelelnek egy-egy tantárgynak, a kerettantervi óraszámok a NAT-ban megadott százalékarányok átszámításából alakultak ki. A 20I2. évi NAT a I2. osztályig bezárólag a müveltségi területek tartalmi elemeit és követelményeit pontosan meghatározta, így a kerettantervek készítőire csupán ezek részletesebb kibontásának és időrendbe illesztésének felelössége hárult.

Az I995. évi NAT valamennyi müveltségi terület közül a legkevesebb tantervi időt (az órakeret 4-8\%-át) a földrajz tantárgynak megfelelő „Földünk és környezetünk” müveltségi terület számára biztosította, és azt - megint egyedüliként - csupán a 7-8. és 9-IO. osztályban szerepeltette. E megoldást a NAT megalkotói maguk se tartották megnyugtatónak (Ballér, 20I3, 9. o.). Ám a helyzet azóta mindössze annyit változott, hogy a müveltségi terület nevét „Földünk-környezetünk”-re helyesbítették, és a 20I2. évi NAT szerint minimális aránnyal (2-4\%) már az 5-6. osztályban is megjelenik, anélkül azonban, hogy ott önálló tantárgy alapját képezné. Az „Életvitel és gyakorlat” nevű müveltségi területen kívül a „Földünk-környezetünk” az egyetlen, amely a II-I2. osztály tantervi anyagából teljesen hiányzik. A földrajznak így kialakult tanrendi helyét és óraszámát a 2. táblázat mutatja.

Az I995. évi NAT körüli viták során a Magyar Földrajzi Társaság nevében Nemerkényi Antal fótitkár memorandumot fogalmazott, amelyet a közoktatásban a földrajz által képviselt számos más szaktudományi társaság közös állásfoglalásaként terjesztettek az oktatási kormányzat, illetőleg a NAT munkálatait irányító Báthory Zoltán államtitkár elé. Az állásfoglalás egységes érvrendszerbe foglalva, tömören és pontosan összegezte a földrajztanítás és általában a korszerü földrajzi müveltség társadalmi jelentőségét. Rámutatott, hogy a NAT hat kiemelt nevelési célkitüzése közül négyben (hon- és népismeret, kapcsolódás Európához és a nagyvilághoz, környezeti nevelés, pályaorientáció) kulcsfontosságú szerepe van a Földünk-környezetünk mủveltségi területnek, ám a NAT-ban elöirányzott szük idökeret miatt a tanterv tartalmi és fejlesztési követelményeinek teljesítése, valamint a kitüzött nevelési célok elérése gyakorlatilag lehetetlen. Az ellentmondás feloldására a memorandum javaslatokat fogalmazott meg, ám ezeket a NAT döntéshozói teljesen figyelmen kívül hagyták. Változatlan időszerüségük okán érdemes ezeket felidézni. Az emlékirat javasolta: - A Földünk-környezetünk mủveltségi terület önálló megjelenítését, bevezetését a közoktatás 5. évfolyamától kezdve.

- Olyan új kerettantervek kidolgozását, amelyek e müveltségi terület legalább heti két órában történő folyamatos oktatását biztosítják az 5-IO. évfolyamokban.

- A müveltségi terület jellegéből fakadóan szükséges gyakorlati, illetve terepi ismeretszerzés lehetőségeinek beépítését a kerettantervekbe.

- Kötelező órakeret előirányzását legalább a gimnáziumok kerettanterveiben az érettségit megelőző II-I2. évfolyamban a globális problémák mélyebb, földtudományi, ökológiai és közgazdasági szempontokat egységbe ötvöző áttekintésére, különös figyelemmel ezen integráló műveltségi terület kiemelkedő szerepére számos természetés társadalomtudomány pályaorientációjában (pl. geológus-, meteorológus-, csillagász-, térképész-, hidrológus-, illetve közgazdászképzés).

\section{A jövő: lehetőségek és kérdőjelek}

A földrajztanítás pedagógiai módszertana jelenleg alapos megújításra szorul. A nemrégiben végzett széles körű kérdőíves felmérések tanúsága szerint ennek legfőbb objektív akadályát tanáraink két egymással szorosan összefüggő tényezőben, nevezetesen $a$ tan- 
anyag elképesztő zsúfoltságában és a szükre szabott tantervi időben látják (Ütőné Visi J., 20II, Probáld, Szilassi és Farsang, 20I5). A korszerü oktatási módszerek - legyen szó cselekedtető és gondolkodtató órai feladatokról, az IKT interaktív alkalmazásáról vagy a projektmódszer elterjesztéséről - jóval időigényesebbek, mint az anyag egyszerü „leadása”. Jogos a kérdés: várható-e, hogy az MFT által közel negyedszázada megfogalmazott igények az új nemzeti alaptanterv bevezetése nyomán legalább részben teljesüljenek? - Az első NAT-tal és a kerettantervvel szerzett tapasztalatok óta földrajztanáraink - a nyomorúságos helyzetbe már-már beletörődve - többnyire borúlátók. De vajon valóban olyan képtelen dolog a földrajz tanítására a mostaninál több és föként észszerübben elosztott időt fordítani? - Érdemes egy pillantást vetni három szomszédos ország tanterveire (2. táblázat), hogy meggyőződjünk róla: egyáltalán nem valóságtól elrugaszkodott kívánságról van szó.

2. táblázat. A földrajz minimális kötelezö órakerete az általános képzést nyújtó alap- és középfokú iskolákban, osztályonként (2017)

\begin{tabular}{lccccccccc}
\hline \multicolumn{1}{c}{ Osztály/orsz. } & 5. & 6. & 7. & 8. & 9. & 10. & 11. & 12. & Össz \\
Magyarország & & & 1 & 2 & 2 & 2 & & & 7 \\
Szlovákia & 2 & 1 & 1 & 1 & 1 & 1 & 1 & $2^{\mathrm{x}}$ & 10 \\
Románia & $1-2^{++}$ & $1-2^{++}$ & $1-2^{++}$ & 2 & 1 & 1 & 1 & 1 & $9-12$ \\
Ausztria $(\mathrm{GW})^{+}$ & 2 & 1 & 2 & 2 & 2 & 1 & 2 & 2 & 14 \\
\hline
\end{tabular}

${ }^{+}=$földrajz és gazdaságtan; $\quad{ }^{++}=$az adott iskola tantervétől függően; $\quad{ }^{x}=12-13$. osztály együtt

A földrajzot mindhárom országban, sőt a táblázatban nem szereplő szomszéd államokban is hazánkhoz képest jóval nagyobb óraszámban tanítják. Ennél még lényegesebb, hogy a tantervi idő osztályok - azaz a tanulók életkora - szerinti elosztása egészen más: tantárgyunk az 5. osztálytól az érettségiig valamennyi tanév anyagában kötelezően megjelenik. Ez egyrészt lehetővé teszi a tantervnek a magyarországitól eltérő, fő vonásaiban lineáris felépitését, ami önmagában is nagymértékben csökkentheti a tartalom zsúfoltságát. Másrészt utat nyit más tantárgyakkal - elsősorban a történelemmel - való észszerübb, összehangolt koncentráció felé, s ez ugyancsak enyhíthetné a földrajzi tananyag terheit. Harmadsorban pedig módot ad azoknak a bonyolultabb, átfogó alapismereteket kívánó témáknak érettebb életkorban való tanítására, amelyek nálunk csak kényszerből kerültek a gimnáziumok alsó osztályainak földrajzi tananyagába.

Az osztrák tanterv példája két további szempontból is tanulságos. Az egyik ilyen szempont a tantárgyak integrációjára, tömbösítésére való törekvés, amely - amerikai mintára - nálunk is évtizedek óta kísért; ott lappang a NAT „müveltségi területeinek” hátterében, 20I6-ban pedig a szakgimnáziumokba hirtelenjében bevezetett „természettudomány" ihletője volt. Nos, az osztrákok 1962-ben egy sajátos, észszerünek és sikeresnek tünő tantárgyi összevonást hajtottak végre „földrajz és gazdaságtan” (Geographie und Wirtschaftskunde, GW) néven. Ez fölöslegessé teszi a gazdasági ismeretek önálló tantárgyba szervezésének nálunk újabban fel-felbukkanó gondolatát, és a földrajzot a vele szoros összefüggésben álló gazdaságtannal társítva olyan integrációt valósít meg, amelynek csírája a földrajz hazai gimnáziumi tananyagában jelenleg is benne rejlik.

Az osztrák tanterv másik tanulságos eleme, hogy a GW ikertestvéreként szerepel benne a „történelem, társadalmi és politikai ismeretek” nevü integrált tantárgy. Ennek tantervi óraszáma az érettségiig bezárólag pontosan megegyezik a földrajz és gazdaságtanéval. Vajon milyen megfontolások indokolhatják, hogy hazánkban a kerettanterv az általános iskola felső tagozatában s a gimnáziumban összesen I8 órát irányoz elő a történelem tanítására, míg a jelen világunkkal foglalkozó földrajzot 7 órába zsúfolja össze? És ugyan mivel magyarázható, hogy miközben a szakgimnáziumok széles köréből az új tanterv 
teljesen számüzte a földrajzot, a történelem bőven mért óraszáma változatlan maradt? (Egyébként a történelem és a földrajz minimális órakerete nemcsak az osztrák, hanem a jóval kötetlenebb brit tantervekben is azonos. A magyarországihoz hasonló torz arányt másutt nehéz lenne találni.)

A fentiekben néhány nemzetközi példát is bemutatva vázoltuk, milyen okokból és miként lenne célszerü változtatni a földrajz jelenlegi tantervi elhelyezésén. Ha azonban a tantárgy számára rendelt óraszám, illetőleg annak időbeni eloszlása mégse változna, és a tanterv lineáris elven alapuló átszerkesztésére se lenne mód, a tanítás módszerének korszerüsítésére akkor is égető szükség lenne. Ehhez másként, mint a tananyag csökkentésével nem lehetne időt nyerni. A kerettantervben több olyan „kapcsolódási pont” is található, amely mögött valójában különböző tantárgyak közötti szükségtelen átfedés rejlik. Nem célunk ezek részletekbe menő vizsgálata s elősorolása, csupán példaként utalunk a Naprendszer és a Világegyetem témakörére, amely a fizikában és a földrajzban egyaránt szerepel, vagy az Európai Unió létrejöttének és müködésének bemutatására, ahol a történelem és a földrajz tananyaga fedi egymást. Az ilyen és hasonló, hagyományosan a földrajz keretében tárgyalt határterületi témákról való lemondás tünhet a tananyagcsökkentés legkevésbé fájdalmas útjának, ám ez is a tantárgy dezintegrációja, szétbontása felé tett lépést jelentene, ami súlyos károkat vonna maga után. Éppen azok a tartalmi és szemléleti vonások mennének veszendőbe, amelyek a földrajz legsajátosabb „hozzáadott értékét” jelentik a közoktatásban, nevezetesen a világról alkotott átfogó kép kialakítása, valamint természet és társadalom kapcsolatrendszerének megvilágítása.

A földrajz tantárgy lényege épp abban rejlik, hogy hidat, összekötő kapcsot képez a természet- és a társadalomtudományok alapjai között; emiatt nem lehet egyik vagy másik műveltségi körbe beskatulyázni. Viszont nyitottsága, sokirányú kapcsolódása, tanárainak szerteágazó alapképzettsége különösen jól érvényesülhet a téma-vagy jelenségközpontú oktatásban. A tantárgyak teljes rendszerének ezzel a koncepcióval történő felváltása azonban csak bizonyos osztályokban, illetőleg iskolatípusokban és az igen távoli jövőben képzelhető el. A hazainál sokkalta szilárdabb alapokon nyugvó finn oktatási rendszerben is csupán a legfelső középiskolai osztályokban kezdtek ezzel kísérletezni, és eredményeit még korai lenne mérlegre tenni.

\section{Összegzés}

Az új nemzeti alaptanterv bevezetése kapcsán - de akár attól függetlenül is - feltétlenül ideje lenne újragondolni az egyes müveltségi területek és tantárgyak számára elöírt tantervi hely- és időarányok kérdéskörét. A földrajz oktatására az első NAT és a rá épülő kerettanterv által biztosított óraszám kevesebb, mint az elmúlt két évszázad története során bármikor volt, és elmarad a szomszédos országokban tapasztalható mértéktől is. Helyzetét a többi tantárggyal és a nemzetközi gyakorlattal összevetve különösen hátrányossá teszi, hogy tanítása a IO. osztályban lezárul. Ez képezi fö akadályát a tantárgy tartalmi és módszertani megújításának, amire pedig eredményes oktatása érdekében égető szükség lenne. A földrajz optimális tantervi helyét alapos elemzés után a jövendő nemzeti közmüveltség iránti felelősség jegyében kellene meghatározni. 


\section{Irodalomjegyzék}

Ballér Endre (2003): Az I995-ös NAT értékelésének néhány kérdése. Iskolakultúra, I3. I2. sz. 3-18.

Cholnoky Jenő (I930): Az Egyenlitötöl a sarkvidékig. Singer és Wolfner, Budapest.

Fodor Ferenc (2006): A magyar földrajztudomány története. MTA FKI, Budapest.

Kant, Immanuel (I80I): Physische Geographie. Bd. I. Vollmer, Mainz-Hamburg.

Probáld Ferenc (I99I): A földrajz az ezredforduló gimnáziumában (Egy új tantervi koncepció vázlata). Iskolakultúra, I. I-2. sz. 58-66.
Probáld Ferenc, Szilassi Péter és Farsang Andrea (20I5): A regionális földrajz helyzete a magyar felsőoktatásban. Földrajzi Közlemények, I39. I. sz. 4I-53.

Udvarhelyi Károly és Göcsei Imre (I973): Az alsó- és a középfokú földrajztanitás története Magyarországon. Tankönyvkiadó, Budapest. I94.

Ütőné Visi Judit (20II): Helyzetkép és lehetőség: a földrajzoktatásról egy felmérés tükrében. Földrajzi Közlemények, I35. 2. Sz. II5-I23.

Vargha György (1908): Reformtörekvések a földrajztanítás terén hazánkban és külföldön. Földrajzi Közlemények, 36. 32-40. 